\title{
Demographic change and income tax revenue in Germany: a microsimulation approach
}

MARTIN BEZNOSKA, Ph.D.* TOBIAS HENTZE, Ph.D.*

Article**

JEL: H24, H68, J11

https://doi.org.10.3326/pse.41.1.8

\footnotetext{
* The authors would like to thank to the two anonymous referees for useful comments and suggestions.

${ }^{* *}$ Received: October 19, 2016

Accepted: January 4, 2017
}

A previous version of this paper was presented at the conference Public Sector Economics organized by the Institute of Public Finance and Friedrich-Ebert-Stiftung in Zagreb on October 14-15, 2016.

\section{Martin BEZNOSKA}

Public Finance Research Unit, Cologne Institute for Economic Research (IW), Konrad-Adenauer-Ufer 21, 50668 Cologne, Germany

e-mail: beznoska@iwkoeln.de

ORCID iD: 0000-0002-9966-221X

Tobias HENTZE

Public Finance Research Unit, Cologne Institute for Economic Research (IW), Konrad-Adenauer-Ufer 21, 50668 Cologne, Germany

e-mail: hentze@iwkoeln.de

ORCID iD: 0000-0003-0900-8554 


\section{Abstract}

As a result of high net migration, both Germany's overall population and its workforce potential are currently growing. However, within a few years this demographic trend will be reversed, leading to a decline in population as a whole and especially in the number of those gainfully employed. In this paper, we use a population projection to apply a static ageing approach to German micro data. Then, we simulate income tax revenue with a microsimulation model for the future population. In 20 years' time the annual price-adjusted income tax loss is estimated to be equal to $€ 18$ billion or almost 7 per cent. This fall in income tax revenue resulting from a shrinking and ageing society will place a huge strain on public finances in Germany, an effect further enhanced by the shift of the tax burden from pension contributions to pension benefits.

Keywords: public finance, tax revenue, demographic change, microsimulation

\section{INTRODUCTION}

Since 2011, Germany's public finances have continuously benefitted from record tax revenues due to a robust economic performance and a solid development of the labour market. Labour market participation and the workforce increased during this time, yielding a plus of about two million employees by 2015. Accordingly, tax revenue from wages and incomes increased massively, putting Germany's public finances in a comfortable budgetary situation. The German budgetary situation yielded surpluses, which eventually reduced the public debt-to-GDP ratio. Since the good economic performance and development of the labour market are expected to last for the next few years especially due to high net immigration, the European Commission (2016) evaluated Germany's situation with respect to fiscal sustainability as being of low risk.

Recent developments regarding the migration of refugees to Germany have contributed to a growing working-age population. In 2015, Germany experienced a net immigration of about 1.1 million people. While about 2 million foreigners immigrated, roughly 0.9 million foreigners emigrated (Federal Statistical Office, 2016). Since this trend is expected to continue in the next years, if to a lower extent, the population projection of the Cologne Institute of Economic Research (IW) predicts a rise in the total population from 82.5 million in 2016 to nearly 84 million in 2024 (Deschermeier, 2016). This projection incorporates continuously high immigration, including an update on the expected number of refugees. It also accounts for refugees going back to their country of origin after a couple of years.

A somewhat different picture is given by the population projection for the time after 2024. Then, the ageing process of society will not be compensated by immigration and demographic changes will reduce the total population year by year. Between 2025 and 2035, the population is expected to shrink by over 700,000 persons (figure 1). This still means a population level above the current value but a steady decline from 2014 onwards. However, due to the higher immigration 
assumed in the projection by IW, it differs from earlier projections, e.g. from Bachmann et al. (2013) or the Federal Statistical Office (2016), that predict a shrinking population in the short run.

\section{Figure 1}

Population projection for Germany (number of inhabitants in millions)

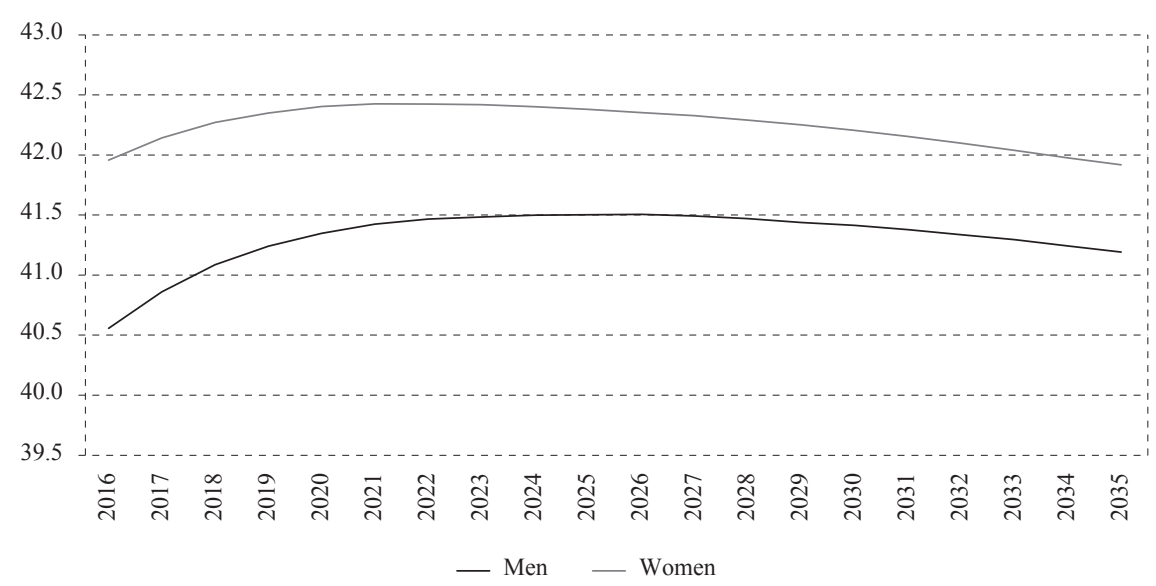

Source: Deschermeier (2016), Federal Statistical Office (2015).

If the focus is placed on the level of total population, the impact and consequences of demographic changes on the economy might be inadequately assessed. The working-age population, which is defined as people from 20 to 64 years, will grow almost at the same rate as the total population within the next years. While the total population will rise by 1.5 million people $(+1.7$ per cent) until 2024 , the working-age population will grow by 0.7 million to a total of 50.8 million persons $(+1.5$ percent $)$. This increase has two reasons. Firstly, the statutory retirement age will be shifted from 65 to 66 in the year 2024 and secondly, the immigrants coming to Germany are predominantly attracted by the positive employment perspectives and, therefore, belong to the working-age group. Even if the process of integrating immigrants and especially refugees into the labour market succeeds only slowly, immigration is expected to raise the number of employees. While the productivity of working refugees is supposed to be lower in the short run, it is assumed to be comparable to that of the original population in the long term.

In the long run, the effect of the ageing population is somehow undetermined. The old-age dependency ratio, which means the number of people in retirement age of 65 and above as a percentage of people between the ages of 20 and 64, will rise from 34 per cent in 2013 to 55 per cent in 2035 according to the prediction of the Federal Statistical Office (2015) in its scenario "Continuity with high immigration". In the underlying study assessed with the IW projection, the ratio will rise to 52.6 per cent in 2035 . If the old-age dependency ratio is defined with a starting age of 67 instead of 65 for the elderly, the value is 45 per cent for 2035 according to the IW projection, while the Federal Statistical Office estimates it to be equal to 
47 per cent. The ratio will be driven by the retirement of the baby boom generation, i.e. in Germany, the birth cohorts between 1955 and 1969, from 2020 onwards.

In this study, the population projection by IW forms the input data for a static ageing approach of representative micro data of the German Socio-Economic Panel (GSOEP). In combination with a microsimulation model that simulates income tax, it is possible to predict the effect of demographic change on income structure and tax revenue. This approach has been applied in the literature; see for example Peichl, Pestel and Schneider (2012), who take a retrospective look at changes in the population structure and evaluate the effect on income distribution. De Blander et al. (2013) also use a population projection for their static ageing model and investigate the income distribution and the interaction with the tax-benefit system in Flanders.

\section{LABOUR MARKET AND FISCAL BUDGET}

While the population structure in the IW projection is given for every year by age and gender from 2016 to 2035 (Deschermeier, 2016), assumptions have to be made with respect to the labour market participation. We start with the assumption of a constant unemployment rate of 4.6 per cent from 2017 onwards according to the definition of National Accounts. Breaking down labour market participation by age group and gender, we base our modelling on the latest available information from 2014 of the microcensus (Mikrozensus). This provides a consistent data base for the weighting factors of the GSOEP data because the population projection by age and gender is based on enhanced census information. Keeping the participation rates constant over the time frame would be an unrealistic scenario because of recent trends: a law shifting the statutory retirement age from 65 years to 67 years was passed in 2007. This shift is to be implemented as a steady procedure ending in 2031, when the statutory retirement age will be 67 years for all new retirees. Since the shift started in 2012, increasing labour market participation rates have been observed for people aged 65 and older. We expect that this trend will continue and therefore anticipate slightly increasing participation rates for the older age groups. Starting with a participation rate of 8.7 per cent for men aged 65 and older in the year 2014, we end up with a rate of 10.4 per cent in 2035. For women in the same age group, the participation increases from 4.0 per cent to 7.0 per cent. The increased participation of the elderly is supposed to spill over to the age groups below, ending in the group from 45 years old upwards. The increase is relatively higher for women assuming a sustained trend of higher labour market participation of women in general (table 1). In summary, the underlying scenario can be seen as a rather optimistic one with a robust labour market and continuing trends in participation. 
TABLE 1

Population and working population by age group (in millions)

\begin{tabular}{|c|c|c|c|c|c|c|c|c|c|}
\hline \multirow{2}{*}{$\begin{array}{l}\text { In the } \\
\text { year }\end{array}$} & \multicolumn{9}{|c|}{ Age group in years } \\
\hline & under 20 & 20-29 & 30-39 & 40-49 & $50-54$ & 55-59 & $60-64$ & 65 and older & Total \\
\hline & \multicolumn{9}{|c|}{$\begin{array}{ll}\text { Female population } \\
\end{array}$} \\
\hline 2016 & 7.3 & 4.8 & 5.0 & 5.7 & 3.5 & 3.1 & 2.7 & 9.9 & 42.0 \\
\hline 2024 & 7.2 & 4.5 & 5.3 & 5.1 & 2.8 & 3.4 & 3.3 & 10.8 & 42.4 \\
\hline \multirow[t]{2}{*}{2035} & 6.9 & 4.1 & 4.7 & 5.5 & 2.7 & 2.5 & 2.6 & 12.9 & 41.9 \\
\hline & \multicolumn{9}{|c|}{ Female workforce } \\
\hline 2016 & 0.5 & 3.6 & 4.1 & 5.0 & 2.9 & 2.4 & 1.3 & 0.4 & 20.3 \\
\hline 2024 & 0.5 & 3.6 & 4.5 & 4.6 & 2.5 & 2.8 & 1.9 & 0.6 & 20.8 \\
\hline \multirow[t]{2}{*}{2035} & 0.4 & 3.1 & 4.1 & 5.1 & 2.4 & 2.0 & 1.5 & 0.9 & 19.5 \\
\hline & \multicolumn{9}{|c|}{ Male population } \\
\hline 2016 & 7.7 & 5.1 & 5.2 & 5.8 & 3.5 & 3.0 & 2.6 & 7.6 & 40.6 \\
\hline 2024 & 7.6 & 4.9 & 5.7 & 5.2 & 2.8 & 3.4 & 3.2 & 8.7 & 41.5 \\
\hline \multirow[t]{2}{*}{2035} & 7.2 & 4.4 & 5.2 & 5.8 & 2.8 & 2.4 & 2.5 & 10.9 & 41.2 \\
\hline & \multicolumn{9}{|c|}{ Male workforce } \\
\hline 2016 & 0.6 & 3.8 & 4.9 & 5.6 & 3.2 & 2.6 & 1.6 & 0.7 & 22.9 \\
\hline 2024 & 0.7 & 4.0 & 5.5 & 5.1 & 2.5 & 3.0 & 1.9 & 0.8 & 23.4 \\
\hline 2035 & 0.6 & 3.4 & 4.9 & 5.7 & 2.5 & 2.1 & 1.7 & 1.1 & 22.0 \\
\hline
\end{tabular}

Source: Deschermeier (2016), Federal Statistical Office (2015), own calculation.

Table 1 shows the population structure in the base year 2016 as well as in 2024 and 2035. While the total population is supposed to grow in the following years and is expected to lie above the 2016 value in the year 2035, the working population is expected to decline in the same period. This development would have implications for the social security system, which are discussed and simulated in the literature on a broad scale (e.g., Deutsche Bundesbank, 2016; Kochskämper, 2016). An increase in the number of people in retirement combined with a decline of the working population will naturally put pressure on pay-as-you-go systems like the German statutory pension system or the health system (Dolls et al., 2015). The relationship between demographic change and tax revenue has been rather disregarded in the literature, with few exceptions (e.g., Decoster, Flawinne and Vanleenhove, 2014). Bach et al. (2002) conclude that the social security system will be more strongly affected by demographic changes than tax revenue.

However, the consequences of an ageing society on incomes, tax base and tax revenue should not be underestimated. A significant share of the social security system is financed via taxes, which results in considerable interdependencies. The statutory pension system was subsidised by nearly 90 billion euro in the year 2016, a sum that comes from the federal budget. The ministry of finance expects it to increase to more than 100 billion euro in 2019. Additionally, civil servants' pensions are completely financed by taxes. The public expenses for civil servants' pensions will increase due to demographic changes in the next few decades (Hentze, 2015). A closer look at tax revenue is worthwhile due to the relationship between the public budget and the social security system. The less 
the fiscal space in the future, the more important will be additional structural changes in the tax system.

German personal income tax applies a progressive tax scale on the sum of total income, which incorporates all sources of market income and pension income. An exception applies for capital income, which is taxed at a constant rate of 25 per cent. The revenue from income tax including the tax on capital income was about 280 billion euro in 2016 , constituting 40 per cent of the total tax revenue in Germany. An important reform of the personal income tax for this analysis was implemented in 2004 - the Retirement Income Law (Alterseinkünftegesetz). The income tax law was reformed by shifting the tax liability from contributions for the statutory pension system to the received retirement incomes. Precisely, the tax-exempted share of contributions continuously increases year by year while the taxable share of old-age income is taxed to a growing extent. The deferred taxation reform will be fully implemented by the year 2040 .

\section{MICROSIMULATION APPROACH AND DATA}

The effect of demographic changes on income tax revenue is simulated in a microsimulation model. The tax and benefit microsimulation model of IW ("STATS"; see Beznoska, 2016) uses the latest data from GSOEP. The GSOEP data is a panel with 30,000 persons in nearly 16,000 households with its current wave from 2014 and provides rich information on income and social-economic characteristics of a representative German population. This information is available on an individual as well as on a household level and enables a detailed simulation of income tax.

To simulate the effect of demographic changes, the population is firstly re-weighted and uprated from 2014 to 2016. This is done by adjusting the weighting factors according to the new population, which comes from the external data described above from census and microcensus. The 2016 population is derived from the uprated census 2011 data, which also forms the base of the IW population projection. The adjustment of the weighting factors includes age group, gender and labour market participation according to the given marginal distributions. The uprating from 2014 to 2016 of the income information in the data set is done differentiated by wage, pension and profit income with factors derived from the National Accounts.

Based on this status quo for 2016, the population is re-weighted according to the population projection to "age" the data. This re-weighting or static ageing of the data yields the marginal distributions, which are shown in table 1. It is technically similar to the approaches in the literature (see e.g., Peichl, Pestel and Schneider, 2012; De Blander et al., 2013).

The re-weighted data are used to simulate the income tax implying an unchanged policy framework. All tax law parameters are kept constant except for future changes that have already passed into law. This affects the deductibility of statu- 
tory old-age provision as well as the deferred taxation of pensions. The income tax law predetermines the parameters of deductibility and deferred taxation until 2040, which are taken into account in the simulation. The individual incomes are fixed on the 2016 level and no growth is assumed, meaning that all results are in real terms of 2016. The modelling also abstracts from productivity changes in the time frame. Thus, all results are solely driven by the demographic changes. The idea is not to construct a realistic future scenario including a prediction of future tax revenue but to isolate the effect of demographic changes on tax revenue in the simulation. Behavioural changes are also neglected.

Besides the base year 2016, we select the years 2024 and 2035 as points in time for the simulation. The year 2024 is selected for two reasons. Firstly, in the course of shifting the statutory retirement age from 65 years to 67 years, the transition to 66 years will be completed in 2024. Secondly, the year 2024 will mark the maximum of total population in the projection. The year 2035 is selected because it marks the end of the IW population projection where the baby boomers will have almost completely retired.

\section{UNCERTAINTIES IN THE STATUTORY PENSION SYSTEM}

A critical assumption regarding income tax revenue is the development of the average retirement income in the statutory pension system. There are three policy parameters in the statutory pension system: the contribution rate, the level of average pension income and the statutory retirement age. It is somehow unclear how these three parameters will be adjusted in the future. Therefore, we take the contribution rate and the transition to a retirement age of 67 years until 2031 as fixed. However, the number of retirees and therefore of pension payments will rise in the simulation in spite of the higher labour market participation of the elderly. This will lead to a financial shortfall in the statutory pension system, which has to be solved via assumptions. The Germany statutory pension system is pay-as-you-go financed, meaning that pension payments are directly financed by the contributions of the working population.

Firstly, we keep the ratio of the sum of contributions to the sum of pension payments, as measured in the data for 2016, constant for the simulations of the future. This basic approach helps to minimise the assumptions about future pension politics. Thus, it implies that pension incomes will be financed with a constant share by employee contributions, which results in a pension income cut if the contributions decline or the number of retirees increases. The distribution of employment patterns, that are crucial for the entitlement to pension income, is also kept constant with no structural changes over time.

Holding the share of contributions to pension incomes constant in the simulation implies an overall cut in pension income of over 9 per cent in 2024 and of over 27 per cent in 2035. This approach stands in conflict with the current law that protects the minimum pension level ( $\$ 154$ SGB VI). The law sets the level of the standard- 
ised pension income in the future, which refers to a pensioner retired at the regular retirement age with 45 years of earning the average wage income. It says that in the year 2020 the projection of the ratio of standardised pension income to the average gross wage income is not allowed to lie below 46 per cent or below 43 per cent in 2030. In 2016, the ratio lies around 47.5 per cent and would drop in the simulation until 2024 and 2035 below the legislated values. To avoid this, we increase the pension income in the simulation to the minimum pension level. We further assume that the minimum pension level, which is only legislated for until 2030, also applies for 2035. This approach accrues an uncovered deficit of 9.5 billion euro in 2024 and of about 39 billion euro in 2035, which are then financed by an increase in the contribution rate (from 18.7 per cent to 22.5 per cent in 2035). As a result, we still end up with an effective pension cut of 4.6 per cent (11.5 per cent) in 2024 (2035) compared to the average pension income in 2016. The treatment of the pension income is rather a stylised updating than a prediction of the future's pension system and shall only enable the modelling of pension taxation. It has to be noted that changes in the average gross wage income are only endogenous to the static ageing of the population because the monetary values are kept in 2016 real terms without any growth.

\section{RESULTS}

Our simulation reveals an increase in the taxable income in the next years (table 2). Aggregated wages will rise due to a higher number of employees. The same applies for pension income, indicating that the ageing of society is already in process. Total wage income will rise by 1 per cent in real terms until 2024, solely as a result of demographics. The expenses for the statutory pensions will be 5.5 per cent higher in 2024. Although taxable income will increase significantly, income tax will decrease because of the transition to deferred taxation. While employees can deduct a higher percentage of their pension contributions, the share of taxable pension income increases. However, the marginal tax rate of employees will be higher than that of retirees. Therefore, the progressive tax scale will yield an overall loss in income tax revenue. Thus, the average income tax burden will decrease below 16 per cent in 2024. After 2024, the total wage income will continuously decrease, while pension income will go sharply up. In spite of a constant unemployment rate, wage income will fall by nearly 90 billion euro per year by 2035 .

The income tax revenue will almost remain at the same level in the near future, but decrease by around 7 per cent per year by 2035 compared to 2016. This corresponds to a minus of 18.4 billion euro in spite of a higher labour market participation of the elderly, which is driven by the effects of demographic change and transition to deferred taxation. The robust estimated confidence interval of 95 per cent lies between 15 billion euro and 22 billion euro and reflects the uncertainties of sampling as well as of the weighting factors. The revenue curve of the social security contributions is driven by the wage incomes but increases due to the higher modelled contribution rate of the statutory pension system in 2035. 
Effects of the demographic change (numbers for Germany for the years 2016, 2024 and 2035 based on simulations from the STATS model)

\begin{tabular}{|c|c|c|c|c|c|}
\hline & \multirow{2}{*}{$\begin{array}{c}2016 \\
\begin{array}{c}\text { in billion } \\
\text { euro }\end{array}\end{array}$} & \multicolumn{2}{|c|}{2024} & \multicolumn{2}{|c|}{2035} \\
\hline & & $\begin{array}{c}\text { in billion } \\
\text { euro }\end{array}$ & $\begin{array}{c}\text { in per cent } \\
\text { compared } \\
\text { to } 2016\end{array}$ & $\begin{array}{c}\text { in billion } \\
\text { euro }\end{array}$ & $\begin{array}{c}\text { in per cent } \\
\text { compared } \\
\text { to } 2016\end{array}$ \\
\hline Wage income & $1,290.9$ & $1,304.0$ & 1.0 & $1,217.4$ & -5.7 \\
\hline Statutory pensions & 245.6 & 259.0 & 5.5 & 280.9 & 14.4 \\
\hline Total income & $1,699.6$ & $1,766.8$ & 4.0 & $1,752.6$ & 3.1 \\
\hline Income tax & 281.3 & 280.3 & -0.3 & 262.9 & -6.6 \\
\hline $\begin{array}{l}\text { Social security } \\
\text { contributions }\end{array}$ & 330.4 & 336.3 & 1.8 & 360.3 & 9.0 \\
\hline Child benefit & 41.0 & 39.4 & -3.9 & 38.1 & -7.2 \\
\hline \multicolumn{6}{|l|}{ memorandum item: } \\
\hline Population in million & 82.5 & \multicolumn{2}{|c|}{83.9} & \multicolumn{2}{|c|}{83.1} \\
\hline
\end{tabular}

Source: GSOEP data v31, own calculation.

These numbers reflect the demographic changes in the short and medium term, which are accompanied by high net immigration. A special characteristic of these changes is observed by the decreasing amount of paid child benefit. This trend indicates an intensifying phenomena. Additionally, the decrease in wage income could have implications for other taxes, like indirect taxes. The shrinking number in the labour force is therefore expected to have a severe impact on public finances.

\section{THE EFFECT OF DEFERRED TAXATION}

Since the working population faces higher marginal tax rates than retirees, the transition to deferred taxation has significant implication for future tax revenue. Since 2005, taxation has continuously been shifted from statutory old-age provision towards pension income, which will be completed by 2040 . This process only unfolds its magnitude over time letting the taxable share of pension income increase year by year to 100 per cent. If the retirement entry is before 2040, a fixed amount of the pension income is tax-exempted while future pension income growth has to be fully taxed. This transition to deferred taxation can be seen as a precautionary policy in expectation of the demographic change. As a result, the revenue from pension taxation will increase for two reasons: firstly, the number of retirees will increase and secondly, the share of taxable pension income will rise slightly over time.

However, the higher taxability of pension income comes along with a higher deductibility of statutory old-age provision, which will diminish the taxable income of employees. Since they will face on average higher marginal tax rates than retirees, overall tax revenue will decrease. This policy-induced revenue effect should be distinguished from the pure demographic effect. In figure 2, the total effect is disaggregated into a deferred taxation and a demographic effect. The year 2030 is added for illustration purposes. The pure demographic effect is simulated 
by ageing the population and holding the tax law according to the 2016 legislation. Thus, the effect of the deferred taxation results from the difference between total and demographic effect.

The decomposition in figure 2 shows that without the transition to the deferred taxation, income tax revenue would be 4 billion euro higher in 2024, about 8 billion euro higher in 2030 and more than 10 billion euro higher in 2035. Initially, the pure demographic effect on the income tax would be positive because of the high net immigration. In 2024, the revenue would be over 3 billion euro higher than 2016. In the long run, the ageing of society would yield a significant decline. In 2030, the negative demographic effect would be nearly 3 billion euro lower than today - this is over 6 billion euro than in 2024. In 2035, the minus would be over 8 billion euro compared to today and nearly 12 billion euro compared to 2024 . This means the revenue will shrink by about 3 per cent in the next 20 years solely due to demographic change. Compared to 2024 this drop will be more than 4 per cent within 11 years. Again, these numbers are in real terms of 2016.

\section{Figure 2}

Decomposition of the income tax revenue effect (effects compared to 2016 income tax revenue in billion euro)

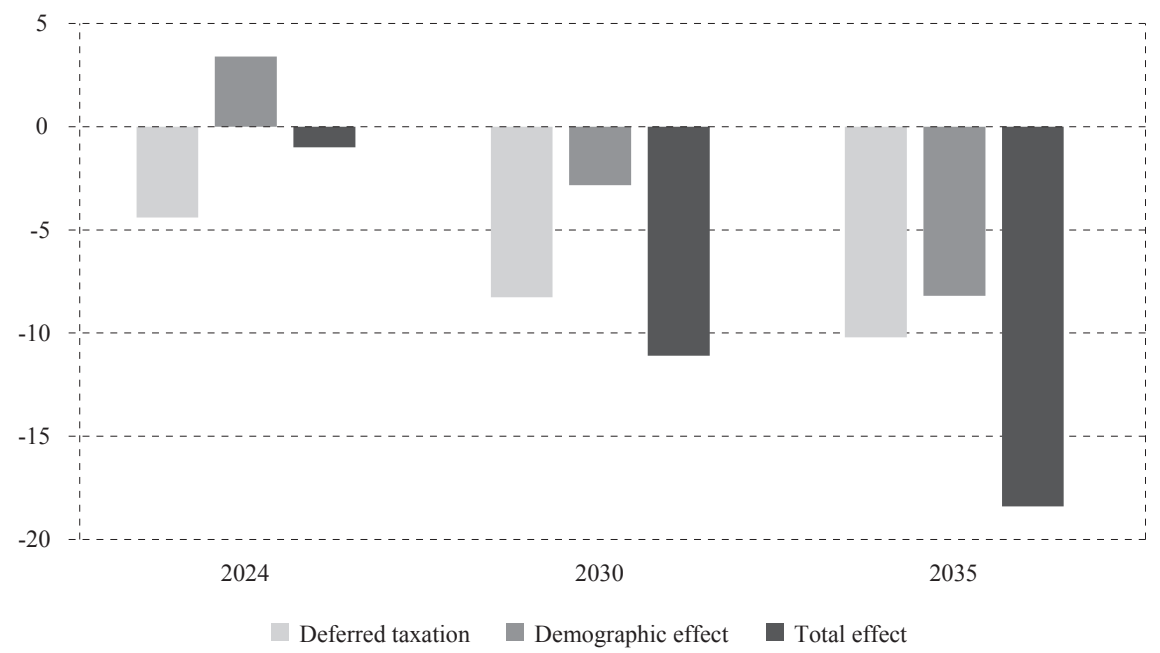

Source: GSOEP data v31, own calculation.

\section{CONCLUSION AND POLICY OPTIONS}

In this paper, we use the IW population projection to apply a static ageing approach on German micro data and simulate the income tax revenue with a microsimulation model for the future population.

In summary, the tax revenue in Germany can be expected to decrease significantly within the next 20 years as a result of two effects: firstly, the ongoing shift from pension contributions to pension benefits is supposed to diminish the overall tax 
revenue since pensioners pay on average lower taxes than employees. Secondly, the labour force is projected to diminish as a result of an ageing population even if net immigration continues as expected.

As a consequence, politicians have a time frame of about two election periods to build a more sustainable system against the background of demographic changes. If not, tax revenue might shrink by 18 billion euro on a price-adjusted level, i.e. not accounting for productivity growth. Increasing the retirement age to 67 years is already considered an eventual measure in this regard.

On the one hand, public finances will be more and more under pressure. On the other hand, employees will benefit from the fact that they can fully deduct their pension contributions from their taxable income (table 3). In contrast, pensioners will likely pay higher taxes since year by year an increasing share of the pension payments will be taxed. The full amount will be taxable by 2040 .

\section{TABLE 3}

Average income tax burden by age group (income tax burden in percentage of gross income)

\begin{tabular}{|c|c|c|c|c|}
\hline $\begin{array}{l}\text { Age group } \\
\text { in years }\end{array}$ & 2016 & 2024 & 2035 & $\begin{array}{c}2035 \text { scenario } \\
\text { "revenue-neutral" }\end{array}$ \\
\hline $18-24$ & 7.3 & 6.9 & 6.3 & 6.8 \\
\hline $25-34$ & 14.6 & 14.0 & 13.0 & 13.9 \\
\hline $35-44$ & 17.3 & 16.6 & 15.8 & 16.8 \\
\hline $45-54$ & 18.3 & 17.7 & 17.0 & 18.2 \\
\hline $55-64$ & 17.8 & 17.4 & 16.8 & 18.0 \\
\hline 65 and older & 7.0 & 8.3 & 9.5 & 10.1 \\
\hline Total & 15.1 & 14.7 & 14.1 & 15.1 \\
\hline
\end{tabular}

Source: GSOEP data v31, own calculation.

Due to the anticipated decreasing tax revenue, the sustainability of public finances is at risk. The developments in the pension system are expected even to worsen the situation since demographic changes will accelerate. A common political response to this development would be an increase in tax rates. If so, even employees over 55 years would pay higher taxes than today and, thus, the benefit from deferred taxation would be overcompensated in this age group (scenario "revenue-neutral" in table 3). Only employees under 45 years would still benefit. Again, any behavioural adjustments are not considered. This is an important note since labour incentives worsen due to the higher tax burden. However, an increasing participation rate by older employees is essential in order to stabilise the whole system and it is a central assumption of the underlying analysis.

To avoid the negative effects resulting from a possible tax hike, politicians should think about alternative approaches. This is especially true as demographic changes will not stop by 2035 (Werding, 2013). The German central bank - Deutsche 
Bundesbank (2016) - has proposed to defer retirement to 69 years by 2060. Supplementarily, a better job integration of migrants, a higher share of women offering their labour or a higher degree, adequate job offers for elder people and an efficient education system are prospective answers to the demographic challenge and the shrinking tax revenue (BMF, 2016b). A similar opposing effect would appear through higher productivity, which would be reflected in higher real wages.

However, all these favourable approaches might not be sufficient. Therefore, public finances should be well prepared for a time of decreasing tax revenue by the establishment of a demographic fund. Current as well as future surpluses could be partly used to finance the effects of demographic changes in 20 years or so. Strict rules are needed concerning, amongst other things, the purpose of such a fund and a precise but flexible payment plan. Against a background of low interest rates and the long-term outlook, an appropriate share of the fund should be invested in the stock market at a reasonable risk exposure.

While these proposals look at the revenue side, it is also necessary to challenge government expenses. The ministry of finance fears deficits in the public finances, since government expenses might surge against the trend of decreasing revenue (BMF, 2016b). The impact of demographic changes on the composition of government expenses is straightforward. An aged society requires a better supply of health and care services while fewer roads, houses or administration officers might be needed by a shrinking population (SVR, 2011:163f).

\section{Disclosure statement}

No potential conflict of interest was reported by the authors. 


\section{REFERENCES}

1. Bach, S. [et al.], 2002. Demografischer Wandel und Steueraufkommen. Research Report. Berlin: German Institute for Economic Research.

2. Bachmann, R. [et al.], 2013. Demografie und Wachstum: Die gesamtwirtschaftlichen Effekte einer höheren Erwerbstätigkeit Älterer. Zeitschrift für Wirtschaftspolitik, 62(1), pp. 287-310. doi: 10.1515/zfwp-2013-0307

3. Beznoska, M., 2016. Dokumentation zum Steuer-, Abgaben- und TransferMikrosimulationsmodell des IW Köln (STATS). IW-Report 27/2016.

4. BMF - Federal Ministry of Finance (Bundesministerium der Finanzen), $2016 \mathrm{a}$. Ergebnis der 148. Sitzung des Arbeitskreises "Steuerschätzungen” vom 02. bis 04. Mai 2016 in Essen, Berlin.

5. BMF - Federal Ministry of Finance (Bundesministerium der Finanzen), 2016b. Vierter Bericht zur Tragfähigkeit der öffentlichen Finanzen, Berlin.

6. De Blander, R. [et al.], 2013. The impact of demographic change on policy indicators and reforms. Flemosi Discussion Paper, DP25.

7. Decoster, A., Flawinne, X. and Vanleenhove, P., 2014. Generational accounts for Belgium, Fiscal Sustainability at a glance. Empirica, 41(4), pp. 663-686. doi: 10.1007/s10663-013-9223-1

8. Deschermeier, P., 2016. Einfluss der Zuwanderung auf die demografische Entwicklung in Deutschland. IW-Trends, 43(2).

9. Deutsche Bundesbank, 2016. Monatsbericht August. Frankfurt/Main: Deutsche Bundesbank.

10. Dolls, M. [et al.], 2015. Fiscal Sustainability and Demographic Change: A Micro Approach for 27 EU countries. IZA Discussion Paper, No. 9618.

11. European Commission, 2016. EU Fiscal Sustainability Report 2015. Institutional Paper 018.

12. Federal Statistical Office, 2015. Bevölkerung Deutschlands bis 2060, 13. koordinierte Bevölkerungsvorausberechnung, Wiesbaden.

13. Federal Statistical Office, 2016. Nettozuwanderung von Ausländerinnen und Ausländern im Jahr 2015 bei 1,1 Millionen [online] Press release, No. 105. Available at: <https://www.destatis.de/DE/PresseService/Presse/Pressemitteilungen/2016/03/PD16_105_12421.html>.

14. Hentze, T., 2015. Anhörung Haushalts- und Finanzausschuss, Gesetz zur Errichtung des Pensionsfonds des Landes Nordrhein-Westfalen, Gesetz über die Feststellung eines vierten Nachtrags zum Haushaltsplan des Landes Nordrhein-Westfalen für das Haushaltsjahr 2015 (Viertes Nachtragshaushaltsgesetz 2015), Drittes Gesetz zur Änderung des Versorgungsfondsgesetzes, Cologne Institute for Economic Research.

15. Kochskämper, S., 2016. Wie lange arbeiten für ein stabiles Rentenniveau?. IW-Kurzbericht 27/2016.

16. Peichl, A., Pestel, N. and Schneider, H., 2012. Does size matter? The impact of changes in household structure on income distribution in Germany. Review of Income and Wealth, 58(1), pp. 118-141. doi: 10.1111/j.1475-4991.2011.00448.x

17. SOEP v31 - Sozio-oekonomisches Panel, 2014, Version 31, Berlin. 
18. SVR - German Council of Economic Experts (Sachverständigenrat zur Begutachtung der wirtschaftlichen Lage), 2011. Herausforderungen des demografischen Wandels, Expertise im Auftrag der Bundesregierung, Wiesbaden.

19. Werding, M., 2013. Modell für flexible Simulationen zu den Effekten des demographischen Wandels für die öffentlichen Finanzen in Deutschland bis 2060: Daten, Annahmen und Methoden. Dokumentation im Auftrag der Bertelsmann Stiftung, Ruhr University of Bochum.

20. Werding, M., 2016. Modellrechnungen für den Vierten Tragfähigkeitsbericht. FiFo-Bericht, No. 20. 